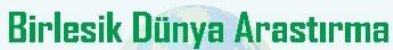 BD-CENTER

www.wj-et.eu

\section{Digitalization of higher education, the crisis of educational culture and Russian economic development}

Olesya E. Labadze ${ }^{{ }^{*}}$, Department of Humanities and Social Sciences, Platov South-Russian State Polytechnic University (NPI), Novocherkassk, Russia https://orcid.org/0000-0001-8584-3477

Aleksandr V. Efimov ${ }^{b}$, Department of Humanities and Social Sciences, Platov South-Russian State Polytechnic University (NPI), Novocherkassk, Russia. https://orcid.org/0000-0003-3177-8045

Vitaly V. Sych ${ }^{c}$, Department of Humanities and Social Sciences, Platov South-Russian State Polytechnic University (NPI), Novocherkassk, Russia. E-mail: https://orcid.org/0000-0001-5837-4767

Nina F. Petrovad, the Department of General and Applied Psychology, North-Caucasus Federal University, Stavropol, Russia. https://orcid.org/0000-0002-6797-158

Irina V. Lipchanskayae, Department of Philosophy and Cultural Studies, Rostov State University of Economics, Rostov-on-Don, Russia. https://orcid.org/0000-0001-7804-440

Natalia S. Ivanenkof, Department of Humanities and Social Sciences, Platov South-Russian State Poly-technic University (NPI), Novocherkassk, Russia. : https://orcid.org/0000-0002-9435-9334

\section{Suggested Citation:}

Labadze, O.E., Efimov, A.V., Sych, V.V., Petrova, N.F., Lipchanskaya, I.V. \& Ivanenko, N.S. (2021). Digitalization of higher education, the crisis of educational culture and Russian economic development. World Journal on Educational Technology: Current Issues. 13(4), 1051-1060. https://doi.org/10.18844/wjet.v13i4.6300

Received from July 19 2021; revised from; August 06, 2021; accepted from October 28, 2021

Selection and peer review under responsibility of Prof. Dr. Servet Bayram, Yeditepe University, Turkey. C2021 Birlesik Dunya Yenilik Arastirma ve Yayincilik Merkezi. All rights reserved.

\begin{abstract}
The problems of digitalization of education and transformation of the Russian culture has been overlooked in the research space. The aim of this research therefore is to report the crisis nature of Russian educational culture, considered in terms of digital innovations of the higher education system. The study was qualitative, and it utilized the transdisciplinary paradigm as a methodological framework. Data was drawn from previous research in different disciplines regarding the topic of interest and the results were analyzed using content analysis. This helped the research to form a holistic view of the phenomena under consideration. The results prove the need to develop a holistic social and philosophical concept of cultural transformation of Russian education to solve the problems and contradictions of transition to digital education and increase the economic growth.
\end{abstract}

Keywords: education, higher education, digitalization of education, digitalization, informatization, onlineization, imitation, culture, culture of education, economic development

* ADDRESS FOR CORRESPONDENCE: Olesya E. Labadze, Department of Humanities and Social Sciences, Platov South-Russian State Polytechnic University (NPI), Novocherkassk, Russia

E-mail address: efimowa.olesya@yandex.ru 
Labadze, O.E., Efimov, A.V., Sych, V.V., Petrova, N.F., Lipchanskaya, I.V. \& Ivanenko, N.S. (2021). Digitalization of higher education, the crisis of educational culture and Russian economic development. World Journal on Educational Technology: Current Issues. 13(4), 10511060. https://doi.org/10.18844/wjet.v13i4.6300

\section{Introduction}

Social and cultural dynamics involves innovations which do not always contribute to the expected positive changes: the result is often expressed in crisis factors and phenomena as some innovations are not tested for compliance with the social and cultural foundations, traditions and norms of society. The Russian researcher Kara-Murza (2013) treated this problem as a cultural crisis and explained the mechanism of its occurrence: they introduce great ideas and innovations that contradict the foundations of a particular culture and disorient people in the context of perception of good and evil, true and false (Kara-Murza, 2013).

It is obvious that a culture (with its own mechanism of reproduction) that performs protective functions in the system of social and cultural development is very sensitive to any external influences and threats, as well as internal changes of radical character (Kuts, 2015). Digitalization processes that cover the entire social spheres affect the deep foundations of Russian culture (and the culture of education) in the most direct and contradictory way.

The scientific community faces a number of issues that require a deep understanding in the light of cultural transformation of education under the influence of information and digital technologies that are being actively introduced into the higher education system. What meaning, value and ideological content will characterize the culture of Russian education in the Digital Age? What will be the cost of the devastating consequences of transition to digital education? Will the emerging digital culture of education be able to cope with the predicted risks associated with its dehumanization? (Non-obvious Risks of Digitalization, 2015).

In this paper we proceed from the hypothesis of crisis nature of cultural transformation of Russian education, the source of which is an extremely inefficiently implemented strategy of digital education (primarily higher education) as the social and cultural basis of society, responsible for reproduction of intellectual and professional potential. Any innovations that destroy the cultural basis of society, the very tradition as a cultural substance, cannot but damage the social and cultural fabric of society, and, consequently, cannot but cause some painful processes. The transition to "digital" education system in modern Russia does not increase its level, potential and quality of education (Yermilova et al., 2019; Karakose \& Bilgin, 2020). Digitalization of education (without taking into account social and cultural foundations, technological and psychological readiness of the education system and its subjects for such radical transformations) is fraught with destructive processes for the entire social and cultural space of Russia.

\section{Literature Review}

Despite the fact that Russian scientists have recently started to discuss digitalization of education in a wide variety of ways, a fairly extensive research and interdisciplinary discourse on the risks and benefits of switching to digital forms and methods of education has already been formed (Strekalova, 2019; Non-obvious Risks of Digitalization, 2015; Uvarov et al., 2019; Valeeva et al., 2017; Valeeva, Karkina \& Starčič, 2018; Karkina, Mena Marcos \& Valeeva, 2021; Tyukavkin, 2019; Shapinskaya, 2019). An extensive discourse in this direction is also presented in foreign scientific literature (Hall, 1996; Anderson, 2003; Bullen, 2007; Meyer, 2010; Robinson, 2010; Radford, 2011; Kentnor, 2015; Alekseeva, 2015; Starcic et al., 2017), since transition to "digital education" in the West had begun long before (Digital education, 2019). In this discourse the key direction is perceived as assessments and forecasts given to digitalization of education. These estimates are the most contradictory ones: their range is not 
Labadze, O.E., Efimov, A.V., Sych, V.V., Petrova, N.F., Lipchanskaya, I.V. \& Ivanenko, N.S. (2021). Digitalization of higher education, the crisis of educational culture and Russian economic development. World Journal on Educational Technology: Current Issues. 13(4), 10511060. https://doi.org/10.18844/wjet.v13i4.6300

limited to positive or negative connotations. There is a search for new approaches to the assessment methodology for Russian education system changes and its digitalization. Thus, from the point of theoretical concept of complexity, scientists justify the need to develop integrative approaches to assess the transformation processes in the field of modern education (Kudashov \& Dumov, 2019).

We should agree with Kashitsin (2020), who, while recognizing the primacy of Russian education system in transition to the Digital Age, proves that it is extremely important to provide the prerequisites for the digital transformation of education, taking into account the conditions and obstacles on this path and the fact that today there are no generally accepted indicators for measuring the effectiveness of digital transformation process (Kashitsin, 2020). In this regard, there is an obvious need to address the cultural foundations of education system development in order to discover the prerequisites and conditions for digitalization of this most important sphere of social and cultural reproduction. Even though the culture of education itself has been the subject of research by Russian scientists (Agapov, 2013; Varova, 2012; Pavlenko, 2015; Vereshchagina, Nechipurenko \& Samygin, 2016; Vodenko, Borovaya \& Efimov, 2020), there is a lack of holistic and conceptual works linking the phenomenon of education culture and its digitalization in modern Russian realities.

This situation determines the need for a holistic conceptual design that includes the problems of digitalization of Russian education and transformation of its cultural foundations in a single subject field from the standpoint of social and philosophical science, which allows to synthesize the methodological and practical experience accumulated in various disciplinary practices.

\section{Methods and Materials}

Culture is a social phenomenon that determines the collective nature and social way of life (Flier, 2017), as well as the course and effectiveness of any innovations introduced into the social space. The question of "What makes some innovations unwelcome by society or become a reason for imitating social practices" is answered by various methodological approaches that are appropriate to use in understanding both the process of digitalization of Russian education and transformation of its culture. Such approaches include the neo-institutional approach (North, 1997), the concept of social inertia (Zakharov, 2018), the theory of historical track (Ilyin, 2017) and the principle of studying social reality as one determined by sociocultural, historical, and civilizational identity of a society with its own logic of evolution. This logic generates the effect of "dependence on the past", on social institutions and dynamics in historical trajectory, on the existing mental programs and attitudes that determine certain social behaviors in various spheres of society: economic, educational, political, family, etc. (Lubsky, Lubsky \& Kolesnikova, 2016; Lubsky, Lubsky \& Chernobrovkina, 2016; Zyubina et al., 2019; Lubsky \& Kovalev, 2020).

These approaches allow us to explain the inefficiency of a greater part of Russian reforms, carried out according to development models of Western society without taking into account Russian social and cultural specifics, its mental, institutional and civilizational originality as a resource base for innovations and prerequisites for their successful implementation in Russian conditions (Aksenova \& Khaliy, 2018).

We used the transdisciplinary paradigm as a methodological framework for this study as the most appropriate social and philosophical strategy for treating the diversity and originality of various disciplinary practices in the field of innovation and crisis processes of the education system caused by digitalization. This approach allows to create a holistic space for research on digital transformation of education and its culture, overcoming fragmentation of knowledge limited by the disciplinary framework of cognition (Lubsky, 2016). It is advisable to turn to the theoretical and applied potential of 
Labadze, O.E., Efimov, A.V., Sych, V.V., Petrova, N.F., Lipchanskaya, I.V. \& Ivanenko, N.S. (2021). Digitalization of higher education, the crisis of educational culture and Russian economic development. World Journal on Educational Technology: Current Issues. 13(4), 10511060. https://doi.org/10.18844/wjet.v13i4.6300

some branches of scientific knowledge, such as Sociology, Political science, Psychology, Economics, History, and Pedagogy, which reveal the problems of Russian education and its culture using their own methodology within the boundaries of specifics of the subject. However, the transdisciplinary paradigm makes it possible to form a holistic view of the phenomena under consideration.

\section{Results}

The culture of education in modern Russian realities is in a "turbulent" state, which corresponds to the state of society as a whole, despite the stages of reforms and attempts to get out of the crisis. The educational culture is the basis of entire educational system of society, and therefore its crisis, caused by both ill-conceived reforms associated with transition to Bologna system and innovations of the digital revolution portends a cultural collapse. As a part of the social culture, which is understood as "a behavioral program ensuring the collective nature of people's life" (Flier, 2017) the culture of education is subjected to the crisis logic of its development. This is manifested in the fact that educational culture (under the pressure of unregulated market relations) loses its social and cultural foundations, risking to become an "appendage" of the market culture. In Russian realities, the market culture is a very dangerous phenomenon which dominant idea is not the power and significance of human rights and interests.

In modern Russian realities the higher education does not cope with the function of social and cultural continuity as the most important feature in determining the trends and prospects of social and cultural dynamics. Education should set the vector and pace of social dynamics, but it is forced to adapt to the market trends and problems, which respond to the challenges of the modern era and digital revolution much faster, forming a request for appropriate specialists (Matei, Rotaru \& Cristache, 2019). Of course, education system cannot fail to respond to the needs of the labor market and changes in the scale of global development. The issue is not information or digital technologies and their resource potential, but their effectiveness in educational process. In Russian reality, the result of introduction of new digital technologies into the educational space is not always positive (Vorontsova, 2004), since a person as an actor of educational activity or a subject of the educational process and educational relations is gradually leaving this educational space (Vorobyov \& Pavlenko, 2016; Tezer et al., 2020).

Thus, digitalization of education, which in Russian conditions proceeds according to the "online scenario", has the key risk of leveling the human factor in organization of educational space. It means, that the culture of education itself is deprived of the main thing - the subject of translation of cultural norms, values and meaning of education.

Nevertheless, experts state, that Russian online education market will expand (Online Education: Can the Internet Replace School, 2020), the issues of transformation of educational culture and its value bases will be even more painful and relevant in the light of consolidation of such Russian social trends as priority of pragmatic values over the instrumental ones or consumer behaviors over the creative and cultural ones (Antropova, Vlasov \& Kasyanenko, 2019; Pechkurov, 2019). These phenomena and processes taking place in the modern Russian society require to find the sources of their appearance and distribution. Taking into account the global context of social and cultural dynamics of Russian society, it is obvious that one of the key sources of negative social and cultural dynamics in our country is the value transformation of education system, which has made possible a paradigm transition and the corresponding changes in educational culture as the fundamental basis of social educational space. Thus, one can argue that the changes taking place in the social and cultural sphere of Russian society (in terms of the new information reality) are largely dramatic, and this drama is primarily associated with 
Labadze, O.E., Efimov, A.V., Sych, V.V., Petrova, N.F., Lipchanskaya, I.V. \& Ivanenko, N.S. (2021). Digitalization of higher education, the crisis of educational culture and Russian economic development. World Journal on Educational Technology: Current Issues. 13(4), 10511060. https://doi.org/10.18844/wjet.v13i4.6300

transformation of Russian education and its culture (Shapinskaya, 2019; Gabdrakhmanova, Turetayeva \& Doszhanova, 2020).

The crisis factors in functioning of the institute of Russian education are linked not only with destruction of educational system that has for centuries been formed in harmony with ideological and civilizational features of Russian people, (based on the great experience and potential of scientific and didactic schools of different eras and generations). These factors are a reflection of the deeper process of transformation or even deformation of Russian educational culture against the background of transformations of the culture as a whole. There is a kind of trap: the culture has become embedded in economic system, gradually blurring its borders and losing its essential purpose and itself in segregation between show business and culture itself.

\section{Discussion}

The education system is one of the most conservative social institutions, (due to the natural traditionalism of society). On the one hand, these qualities allow the system (and society) to maintain its internal integrity and ensure a reliable transfer of traditional values. On the other hand, conservatism prevents the education system from flexible response to the needs of economy. The key to its effectiveness lies in innovations, that is, in constant updating ("Digital" education: Let no one Remain Superfluous, 2019). They should investigate the global trends and factors related to digitalization and informatization of the social sphere (Bakaeva, Stepanov \& Stepanova, 2018) and education (Savard et al., 2019; Verbitsky, 2019).

The sources of crisis factors in social and cultural dynamics of Russian society and its education system are to a certain extent lagging behind the advanced technologies and innovations used in the world educational practice, but internal factors also play an important role. In a short period of time, the entire educational space created by the Soviet society in the aggregate space of its scientific and didactic schools, educational ties and state support was destroyed, there were introduced innovations of non-Russian origin, alien to the culture of Russian education, which has already cracked so much and is unable to resist critical innovations or process them in its own (already quite blurred) social and cultural landscape.

Thus, it is necessary to take into account the influence of processes derived from internal environmental factors that affect transformation of the institute of education, the academic environment with its ethos, corporate culture and the culture of education in general. We can state, that in Russian higher education system there has been a paradigmatic transition, jeopardizing the former educational culture, which turned out to be inadequate to the purposes and character introduced in the educational field of information, communication and digital technology. In scientific and public discourse all that resulted into the problem of "networkization", "virtualization", "onlineization" and "cybernetization" of educational environment and education in general (Bogoslovsky \& Aniskin, 2018). Scientists agree to treat meeting the global trends of digitalization due to the total penetration of information and digital technologies into social life as the norm of modern education, which cannot remain aloof from global processes and trends (Grebennikova \& Novikova, 2019), but transition to digital education should not be accompanied by a crushing blow to the social or cultural basis and educational culture, which is formed in the logic of civilizational dynamics, its ideological foundations and cultural traditions.

However, this is exactly what is happening with Russian education system, as evidenced by the facts related to standardization, unification and simplification of the educational process, the loss of 
deep meanings of education, the growth of imitation schemes and strategies in educational practices and management of Russian education (Pavlenko, 2015).

An innovative social breakthrough is impossible in an "empty place", i.e. in a society that has lost its social and cultural basis. This basis, represented by the culture of education with great didactic experience and potential of scientific schools may form an effective platform for progressive innovations that cannot bring effect without a social and cultural basis (Surkova, 2018). Innovations that do not correspond to these grounds are rejected by society, often causing archaic phenomena, triggering inertial processes and (even more dangerous) imitative practices. Russian philosophers state, that in the field of education these processes take place due to the archaic vector of transformation of the modern Russian state (Kumykov \& Sitnikov, 2019).

\section{Conclusion}

In conclusion we should raise a number of questions designed to answer the main one: what should the culture of education in the digital age be. The answer suggests another question: is it possible for the educational culture to become an integral, stable set of meanings, ideas, values and attitudes able to form and reproduce the space of education in the logic of social and cultural trajectory and uniqueness of society? The author's definition of educational culture in this version clearly does not fit the dynamics of digital education, digital age and the mobile world, where the principles of constancy, stability and tradition are no longer relevant. They have been replaced by such symbols of modernity as variability, movement, dynamics and mobility as markers of social success (Urry, 2012).

The modern system of Russian higher education is not ready to form this type of personality for such a mobile type of society. However, it is forced to move in this direction, destroying everything that is focused on formation of a different type of personality and society. So, the "policy of extremes", traditionally implemented by the Russian government in social sphere, has led to extremely dangerous situations. There takes place growth of simulation practices in the field of education, when "online" education is often replaced by "remote" education, so digitalization of education is presented in the format of onlineization in conditions of rapid transition to online forms of educational practices and management. Psychological and technical unavailability of digital education in the country as a whole (rather than in its most advanced universities) in terms of resources and technologies automatically launched the mechanisms of digital imitation of educational process. The culture of education is also threatened by such imitation, which can contribute to the long-running processes of destruction of the value and semantic integrity of the cultural basis of Russian education system.

\section{Acknowledgments}

The research was performed within the grant of the President of the Russian Federation for state support for the leading scientific schools of the Russian Federation (NSh-2582.2020.6) «Public policy in the field of higher education and development of innovative potential of youth: economic and noneconomic determinants and mechanisms in the conditions of regionalization of social space and the formation of industry 4.0 »

\section{References}


Labadze, O.E., Efimov, A.V., Sych, V.V., Petrova, N.F., Lipchanskaya, I.V. \& Ivanenko, N.S. (2021). Digitalization of higher education, the crisis of educational culture and Russian economic development. World Journal on Educational Technology: Current Issues. 13(4), 10511060. https://doi.org/10.18844/wjet.v13i4.6300

Agapov, Yu.V. (2013). Culture of Education and Formation of the Subject of Educational Activity. Gramota, 6(32). URL: www.gramota.net

Aksenova, O.V. \& Khaliy, I.A. (2018). The Modern Development. Setting the Research Topic. Vestnik Instituta sociologii, 24, 13-26. https://www.isras.ru/index.php?page id=771\&pid=175

Alekseeva, L., Shaidullina, A., Lipaev, A. \& Sadykova, L. (2015). Informal environment in occupational English training. International Multidisciplinary Scientific GeoConference Surveying Geology and Mining Ecology Management, SGEM, 3(5), 909-915. https://elibrary.ru/item.asp?id=24969335

Anderson, T. (2003). Getting the Mix Right Again: An Updated and Theoretical Rationale for Interaction. International Review of Research in Open and Distance Learning, 4(2), 1-14. http://www.irrodl.org/index.php/irrodl/article/view/149

Antropova, M. Y., Vlasov, A. A., \& Kasyanenko, E. F. (2019). Mobile technologies in educational process Chinese universities. New Trends and Issues Proceedings on Humanities and Social Sciences, 6(5), 1-7. https://doi.org/10.18844/prosoc.v6i5.4367

Bakaeva, Zh.Yu., Stepanov, A.G. \& Stepanova, S.E. (2018). Philosophical and methodological foundations of informatization and modeling in the context of digitalization of society. Kontekst i refleksija: filosofija o mire $i$ cheloveke, 7(5A), 20-27. http://publishing-vak.ru/file/archive-philosophy-2018-5/journal-philosophy2018-5a.pdf\#page $=30$

Bayanova, A.R, Sabaeva, E.K., Sakhipova, Z.M., Zatsepina, M.B., Tararina, L.I., Votinov, A.A. \& Ilkevich, K.B. (2019). Educational Environment Ecology as Factor of University Teacher Health Saving in Context of Education and Science Reforms in Modern Russia. Ekoloji, 28(107), 4937-4941. http://www.ekolojidergisi.com/article/educational-environment-ecology-as-factor-of-university-teacherhealth-saving-in-context-of-7072

Bogoslovsky, V.I. \& Aniskin, V.N. (2018). The Role and Place of Holistic Informational and Educational Environment at the Stage of Digitalization of Learning and Character Education. Samarskij nauchnyj vestnik, 4(25), 305311. https://snv63.ru/2309-4370/article/view/21892

Bullen, M. (2007). Participation and Critical Thinking in Online University Distance Education. International Journal of E-Learning \& Distance Education, 13(2), 1-32.

Digital Education. (2019). Let no one Remain Superfluous. URL: https://www.kommersant.ru/doc/4171063

Flier, A.Ya. (2017). Theory of Culture: Experience of Generalization. Kul'tura kul'tury. URL: http://cult-cult.ru/thetheory-of-culture-a-new-generalization/

Gabdrakhmanova, S., Turetayeva, G., \& Doszhanova, S. (2020). Perspectives and Problems of Inclusion Education in Kazakhstan during Covid 19. International Journal of Special Education and Information Technologies, 6(1), 29-36. https://doi.org/10.18844/jeset.v6i1.5478

Grebennikova, V.M. \& Novikova, T.V. (2019). On the Issue of Digitalization of Education. Istoricheskaja i social'noobrazovatel'naja mysl', 11(5), 158-165. https://cyberleninka.ru/article/n/k-voprosu-o-tsifrovizatsiiobrazovaniya

Hall, P. (1996). Distance Education and Electronic Networking. Information Technology for Development, 7(2), 7589. https://www.tandfonline.com/doi/abs/10.1080/02681102.1996.9525271

Ilyin, V.I. (2017). Structure of the Historical Track of Russia: Problems of Methodology. Mir Rossii. Sociologija. Jetnologija, 4, 30-50.

Karakose, K., \& Bilgin, M. . (2020). A new strategy for curriculum learning using model distillation. Global Journal of Computer Sciences: Theory and Research, 10(2), 57-65. https://doi.org/10.18844/gics.v10i2.5810 
Labadze, O.E., Efimov, A.V., Sych, V.V., Petrova, N.F., Lipchanskaya, I.V. \& Ivanenko, N.S. (2021). Digitalization of higher education, the crisis of educational culture and Russian economic development. World Journal on Educational Technology: Current Issues. 13(4), 10511060. https://doi.org/10.18844/wjet.v13i4.6300

Kara-Murza, S. (2013). Destruction of Culture. URL: http://rossiyanavsegda.ru/read/513/

Karkina, S.V., Mena Marcos, J. \& Valeeva, R.A. (2020). Design of Online Course based on SPOC as a Signature Pedagogy in Music Teacher Education. ACM International Conference Proceeding Series, 3436576, 870-876. https://dl.acm.org/doi/abs/10.1145/3434780.3436576

Karkina, S.V., Mena Marcos, J.J. \& Valeeva, R.A. (2021). Improvement of Art Creative Skills by the Means of Signature Pedagogy in Online Musical Education. Communications in Computer and Information Science, 1344, 86-99. https://link.springer.com/chapter/10.1007/978-3-030-67435-9 7

Kashitsin, V.P. (2020). Research of the Digitalization Process in the System of General Education in Russia. Otechestvennaja i zarubezhnaja pedagogika, 3(68), 52-65. https://cyberleninka.ru/article/n/issledovanieprotsessa-tsifrovizatsii-v-sisteme-obschego-obrazovaniya-rossii

Kentnor, H. (2015). Distance Education and the Evolution of Online Learning in the United States. Curriculum and Teaching Dialogue, 17(1-2), 28-29. https://tinyurl.com/rn543p45

Kudashov, V.I. \& Dumov, A.V. (2019). Informatization and Digitalization: a Complex Approach to Assessing the Transformation of Education. Professional'noe obrazovanie $v$ sovremennom mire, 9(4), 3176-3186. https://profed.nsau.edu.ru/jour/article/view/618

Kumykov, A.M. \& Sitnikov, A.P. (2019). Archaization in Educational Practices in Modern Russian Society. Gumanitarij Juga Rossi, 1, 261-269. https://www.jour.fnisc.ru/index.php/hsr/article/view/6221

Kuts, V.A. (2015). Protective Functions of Culture. Kul'tura kul'tury, 2. URL: http://cult-cult.ru/protective-functionsof-culture/

Kvon, G.M., Vaks, V.B., Kalimullin, A.M., Bayanova, A.R., Shaidullina, A.R., Dolzhikova, A.V. \& Lapidus, N.I. (2019). Developing the Informational and Digital Environment of a University: Problem Analysis and Assessment. Eurasia Journal of Mathematics, Science and Technology Education, 15(10), 1841-1848. https://www.ejmste.com/article/developing-the-informational-and-digitalenvironment-of-a-university-problem-analysis-and-assessment-7719

Lubsky, A.V. (2016). Transdisciplinary Research: Problems of Modern Epistemological Discourse. Gumanitarnye, social'no-jekonomicheskie i obshhestvennye nauki, 12, 61-66. https://cyberleninka.ru/article/n/17053196

Lubsky, A.V., Kolesnikova, E.Y. \& Lubsky, R.A. (2016). Mental Programs and Social Behavior Patterns in Russian Society. International Journal of Environmental and Science Education, 11(16), 9549-9559. https://eric.ed.gov/?id=EJ1118877

Lubsky, A.V., Lubsky, R.A. \& Chernobrovkina, N.I. (2016). Mental Programs and Models of Economic Behavior in the Russian Society. Journal of Applied Economic Sciences, 11(7), 1405-1412. https://www.ceeol.com/search/article-detail?id=533597

Lubsky, A.V. \& Kovalev, V.V. (2020). From "Onlineization" of High School to Online Education. Gumanitarij Juga Rossii, 9(2), 33-50. https://www.jour.fnisc.ru/index.php/hsr/article/view/7194

Matei, A., Rotaru, F. G., \& Cristache, S. E. (2019). Characterisation of structure and trends in the higher education. International Journal of Learning and Teaching, 11(2), 66-76. https://doi.org/10.18844/ij|t.v11i2.515

Meyer, K.A. (2010). If Higher Education Is a Right, and Distance Education is the Answer, Then Who Will Pay? Journal of Asynchronous Learning Networks, 14(1), 45-68. https://eric.ed.gov/?id=EJ909841

Non-obvious Risks of Digitalization. (2015). What Education is Going to Become. URL: https://sn.ria.ru/20191211/1562209433. 
Labadze, O.E., Efimov, A.V., Sych, V.V., Petrova, N.F., Lipchanskaya, I.V. \& Ivanenko, N.S. (2021). Digitalization of higher education, the crisis of educational culture and Russian economic development. World Journal on Educational Technology: Current Issues. 13(4), 10511060. https://doi.org/10.18844/wjet.v13i4.6300

North, D. (1997). Institutions, Institutional Change and Economic Performance. Trans. from English by A. N. Nesterenko; preface and scientific ed. by B.Z. Milner. Moscow: Fond jekonomicheskoj knigi «Nachala». https://jonnyphillips.github.io/FLS6415/Class 2/North\%201990.pdf

Online Education: Can the Internet Replace School? (2020). URL: https://trends.rbc.ru/trends/education/5de126b59a79475b973cd3d3 .

Pavlenko, I.I. (2015). Informatization of Social Management and Prospects for Formation of an Innovative University in Russia: PhD Thesis. Rostov-on-Don: Pyatigorsk State Linguistic University. https://static.freereferats.ru/ avtoreferats/01007987006.pdf

Pechkurov, I.V. (2019). Glamorous Sociality and Demonstrative Consumption in Russian society. Gumanitarij Juga Rossii, 8(2), 214-221. https://cyberleninka.ru/article/n/18082521

Piralova, O.F., Gerasimenko, S.A., Kuznetsov, V.V., Popova, O.V., Subbotin, G.V., Kolomyts, O.G., \& Mashkin, N.A. (2020). Gaming Industry Trends in new Generation Specialist Training in University Environment. Journal of Environmental Treatment Techniques, 1132-1135. http://www.jett.dormaj.com/docs/Volume8/Issue\%203/Gaming\%20Industry\%20Trends\%20in\%20new\%2 0Generation\%20Specialist\%20Training\%20in\%20University\%20Environment.pdf

Radford, A.W. (2011). Learning at a Distance: Undergraduate Enrollment in Distance Education Courses and Degree Programs. URL: https://nces.ed.gov/pubs2012/-2012154.pdf .

Robinson, K. (2010). Changing Education Paradigms. https://www.ted.com/talks/ken robinson changing education paradigms

Savard, C., Sari, A., Venet, P., Nikulina, A., \& Dupuis, J. (2019). The EFQM method to compare battery performance. Global Journal of Business, Economics and Management: Current Issues, 9(1), 41-54. https://doi.org/10.18844/gibem.v9i1.4044

Shapinskaya, E.N. (2019). Education in the "Digital Era": a Doctrine or Entertainment? Kul'tura kul'tury, 2. URL: http://cult-cult.ru/education-in-the-digital-age-learning-or-entertainment/ .

Starcic, A.I., Huang, P.-S., Valeeva, R.A., Latypova, L.A., Huang, Y.-M. (2017). Digital storytelling and mobile learning: Potentials for internationalization of higher education curriculum. Lecture Notes in Computer Science (including subseries Lecture Notes in Artificial Intelligence and Lecture Notes in Bioinformatics), 10676 LNCS, 400-406. URL: https://www.scopus.com/inward/record.uri?eid=2-s2.085041441247\&doi=10.1007\%2f-978-3-319-710846 45\&partnerlD=40\&md5=f8ce91308c54fbc694b22a9fe2960c0d

Strekalova, N.B. (2019). Risks of Introducing Digital Technologies in Education. Vestnik Samarskogo universiteta. Istorija, pedagogika, filologija, 25(2), 84-88. https://dt.giac.by/jour/article/view/608

Surkova, I.V. (2018). Social Sphere of Russian Society: at the Intersection of Traditions and Innovations. Rostov-onDon: Fond nauki i obrazovanija.

Tezer, M. ., Ulgener , P., Minalay , H., Ture, A. ., Tugutlu , U. ., \& Harper , M. G. . (2020). Examining the relationship between academic procrastination behaviours and problematic Internet usage of high school students during the COVID-19 pandemic period. Global Journal of Guidance and Counseling in Schools: Current Perspectives, 10(3), 142-156. https://doi.org/10.18844/gigc.v10i3.5549

Tugun, V., Bayanova, A.R., Erdyneeva, K.G., Mashkin, N.A., Sakhipova, Z.M. \& Zasova, L.V. (2020). The Opinions of Technology Supported Education of University Students. International journal of emerging technologies in learning, 15(23), 4-14. https://www.learntechlib.org/p/218460/

Tyukavkin, N.M. (2019). Digitalization of Educational Processes in Higher Education Institutions. Jekspert: teorija $i$ praktika, 1(1), 35-41. https://cyberleninka.ru/article/n/tsifrovizatsiya-obrazovatelnyh-protsessov-v-vuzah 
Labadze, O.E., Efimov, A.V., Sych, V.V., Petrova, N.F., Lipchanskaya, I.V. \& Ivanenko, N.S. (2021). Digitalization of higher education, the crisis of educational culture and Russian economic development. World Journal on Educational Technology: Current Issues. 13(4), 10511060. https://doi.org/10.18844/wjet.v13i4.6300

Urry, J. (2012). Mobilities. Translated from English by A.V. Lazareva. Moscow: Praksis.

Uvarov, A.Yu., Dvoretskaya, I.V., Zaslavskiy, I.M., Karlov, I.A., Mertsalova, T.A. \& Frumin, I.D. (2019). Difficulties and prospects of digital transformation of education. Moscow: Izd. dom Vysshej shkoly jekonomiki. https://elibrary.ru/item.asp?id=39198135

Valeeva, R.A., Karkina, S.V. \& Starčič, A.I. (2018). Distance learning for aesthetic education - Informed professional development and life-long learning of student teachers. ACM International Conference Proceeding Series, pp. 597-603. URL: https://tinyurl.com/n3f4h5rh

Varova, N.L. (2012). Culture of Education in Modern Civilization. Sovremennye problemy nauki i obrazovanija, 4.

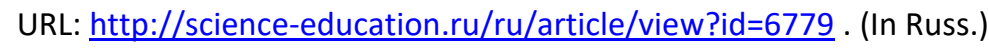

Verbitsky, A.A. (2019). Digital Learning: Problems, Risks and Prospects. Jelektronnyj nauchno-publicisticheskij zhurnal "Homo Cyberus", 1(6). URL: http://journal.homocyberus.ru/Verbitskiy_AA_1_2019. (In Russ.) http://journal.homocyberus.ru/Verbitskiy AA 12019

Vereshchagina, A.V., Nechipurenko, V.N. \& Samygin, S.I. (2016). Value Crisis of Modern Education in Historical Projection and Dynamics of Modernization of its Paradigmatic Foundations in the Context of Information Age Challenges. Kontekst i refleksija: filosofija o mire i cheloveke, 2, 74-91. http://publishingvak.ru/file/archive-philosophy-2016-2/7-vereshchagina-nechipurenko-samygin.pdf

Vodenko, K.V., Borovaya, L.V. \& Efimov, A.V. (2020). Russian Education in the Context of Global Informatization and Digitalization: Socio-philosophical Discourse. Gumanitarij Juga Rossii, 9(3), 36-44.

Vorobyov, G.A. \& Pavlenko, I.I. (2016). Trends and Prospects of Informatization of Social Management in Modern Conditions. Gumanitarij Juga Rossii, 20(4), 144-151.

Vorontsova, E.V. (2004). Informatization of Modern Russian Society as an Innovative Process: a Sociological Analysis: PhD Thesis. Moscow: Russian State Social University. https://static.freereferats.ru/ avtoreferats/01002632257.pdf

Yermilova, V.V., Loktionova, Y.N., Smirnov, A.V., Seregina, T.N., \& Prokopyev, A.I. (2019). The development of a personal wellbeing index -indicator of the life satisfaction. Espacios, 40(25), Article number 16. https://www.revistaespacios.com/a19v40n25/19402516.html

Zakharov, V.K. (2018). Historical Inertia of Self-awareness and Self-organization of Society. Bol'shaja Evrazija: Razvitie, bezopasnost', sotrudnichestvo, 1-2, 615-617.

Zyubina, I.A., Dzyubenko, A.I., Borisenko, V.A., Popova, O.V., \& Prokopyev, A.I. (2019). Implicit Linguopragmatic Strategies of Speech Behavior of English-Speaking Prosecutors. XLinguae, 12(4), 92-102. https://www.rea.ru/ru/org/managements/orgnirupr/Documents/666-

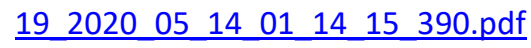

